\title{
Effect of Modified Atmosphere Packaging on Headspace Gas Concentrations Including Volatiles and Sensorial Attributes of Fresh-Cut Lettuce
}

\author{
Manpreet Kaur, S.S. Dhumal", V.K. Garande, D.R. Patgaonkar, \\ A.G. Bhoite and S.S. Patil \\ Department of Horticulture, College of Agriculture, Kolhapur - 416004, \\ (MPKV Rahuri), Maharashtra, India \\ *Corresponding author
}

\begin{tabular}{|l|}
\hline K e y w o r d s \\
$\begin{array}{l}\text { Fresh-cut lettuce, } \\
\text { Modified atmosphere } \\
\text { packaging, Carbon } \\
\text { dioxide, Oxygen, } \\
\text { volatiles, Shelf-life, } \\
\text { Quality. }\end{array}$ \\
\hline Article Info \\
\hline $\begin{array}{l}\text { Accepted: } \\
\text { 17 September } 2017 \\
\text { Available Online: } \\
\text { 10 November } 2017\end{array}$
\end{tabular}

The effect of different modified atmosphere packaging (MAP) treatments on the headspace gas concentrations and sensorial attributes of fresh-cut lettuce cv. GKL-2 during refrigerated storage $\left(5 \pm 1^{0} \mathrm{C}\right)$ was studied at Post harvest Laboratory of Horticulture Section, College of Agriculture, Kolhapur. Five different MAP packaging viz., 100\% nitrogen $\left(\mathrm{N}_{2}\right)$, 95\% nitrogen $\left(\mathrm{N}_{2}\right)$ plus $5 \%$ oxygen $\left(\mathrm{O}_{2}\right), 10 \%$ carbon dioxide plus $3 \%$ oxygen, and perforated film packaging (10 holes@1.5 mm per packet) including air (Passive MAP) as control treatment were undertaken for study. The changes in headspace gas concentrations including volatiles were slow in the fresh-cut lettuce packaged with $10 \%$ carbon dioxide and $3 \%$ oxygen upto 15 days at $5 \pm 1{ }^{\circ} \mathrm{C}$. Decrease in oxygen $(\%)$ and increase in carbon dioxide $(\%)$, ethylene $(\mathrm{ppm})$, acetaldehyde $\left(\mu \mathrm{LL}^{-1}\right)$ and ethanol concentration was observed in all post-harvest treatments. The packaging of lettuce with carbon dioxide $(10 \%)$ and oxygen $(3 \%)$ recorded minimum decrease in oxygen and increase in carbon dioxide, ethylene, acetaldehyde and ethanol concentrations. The maximum changes in headspace gas concentrations including volatiles viz. acetaldehyde and ethanol were observed in perforated packaging treatment followed by air/passive MAP. Carbon dioxide (10\%) and oxygen (3\%) MAP was best in retaining the sensory attributes viz. color and appearance, taste, flavor, crispness and overall acceptability.

\section{Introduction}

The preparation and distribution of fresh-cut vegetables is a rapidly developing industry that provides the consumers with conventional and nutritious food. Fresh-cut products are commonly consumed directly from the bags without any further rinse, a convenience that is one of the main reasons for the growing popularity of these products (Rico et al., 2006). The beneficial effect has been attributed to non-essential food constituents, phytonutrients that pose a relevant bioactivity when frequently consumed as a part of regular diet (Steinmetz and Potter, 1996). Fresh-cut fruits \& vegetables emerged to fulfill this new consumer's demands of healthy palatable and easy to prepare plant food (Allende et al., 2006). Over the last years, the market for minimally processed vegetables is growing both in sales volume and assortment of vegetables, e.g. vegetables salads of endive, lettuce, carrots, pepper, potatoes, onions, 
cabbage, soybean, both as single vegetables and in mixtures, completed with sauces and dressings, as well as vegetables mixtures for soups and stew (Dash et al., 2013). Lettuce is currently consumed in minimally processed fresh-cut and ready to use forms. Fresh-cut lettuce, which represent more than $80 \%$ of the total production of fresh-cut produce, has been one of the more highly requested commodities by fast food services and salad bars over the past decade (Beltran et al., 2005). But the minimal processing cause surface damage increasing lightly the tissue respiration and leading to biochemical deterioration of the fresh-cut fruits and vegetables (Martin-Belloso et al., 2006). Therefore, new technique for maintaining quality and inhibiting undesired microbial growth of fresh cut products are demanded in all steps of the production and distribution chain. The number of processing techniques currently used by the fresh cut industry is use of antioxidants, surfactants, sanitizers and modified atmosphere packaging (MAP). Modifying the atmosphere surrounding a food product allow the preservation of fresh state of the product without the temperature or chemical treatments used by competitive preservation techniques, such as canning, freezing, dehydration and other processes. Oxygen carbon dioxide and nitrous oxide are most often used in MAP (Sandhya, 2015). Oxygen is probably the most important gas in this context being used metabolically by both aerobic spoilage microorganisms and plant tissues and taking part in some enzymatic reactions in food including the compounds such as vitamins and flavours. Carbon dioxide is most effective in foods where the normal spoilage organisms consist of aerobic, gramnegative psychrotropic bacteria (Church, 1994). The objective of this research was to determine the effect of modified atmosphere gas packagings on headspace gas concentrations including volatiles and sensorial attributes of fresh-cut lettuce.

\section{Materials and Methods}

\section{Sample preparation}

The healthy and fresh lettuce leaves cv. GKL2 obtained from the Instructional-cumresearch farm of Horticulture section, College of Agriculture, were used for experiment. Lettuce leaves were hand-harvested using disinfected scissors. On the same day, the lettuce leaves were transported to the laboratory in a thermocole boxes. The leaves were washed in $200 \mu \mathrm{LL}^{-1}$ chlorine solution and were surface dried under ambient conditions. Defective and damaged leaves were discarded. After weighing, the lettuce leaves were gently cut in pieces of $5 \mathrm{~cm}$ wide using a sharp knife. The cut lettuce was held for $1 \mathrm{~min}$ in running tap water immediately, and then excess water drained on a stainless steel mesh for 5 minutes. The fresh-cut lettuce pretreated with ozonated water plus calcium lactate solution was air dried and packed in polypropylene bags with different atmosphere modifications. The packagings were carried out with hand sealer in a closed glass chamber with desirable modified atmosphere concentrations. The healthy and fresh-cuts pretreated leaves were divided into lots for further packaging treatment viz. Air or passive MAP, $100 \%$ nitrogen $\left(\mathrm{N}_{2}\right), 95 \%$ nitrogen $\left(\mathrm{N}_{2}\right)$ plus $5 \%$ oxygen $\left(\mathrm{O}_{2}\right), 10 \%$ carbon dioxide $\left(\mathrm{CO}_{2}\right)$ and $3 \%$ oxygen $\left(\mathrm{O}_{2}\right)$. The pretreated fresh-cut lettuce leaves weighing $250 \mathrm{~g}$ were filled in each presterlized polypropylene bag and were flushed with different modified atmosphere packaging. Flushed pretreated fresh-cut lettuce leaves samples sealed in polypropylene bags were kept in refrigerated storage at $5 \pm 1{ }^{0} \mathrm{C}$.

\section{Head space gas concentrations including volatiles}

The in-package atmosphere $\left(\mathrm{O}_{2}, \mathrm{CO}_{2}\right)$ was measured with a portable headspace $\mathrm{O}_{2}$ and 
$\mathrm{CO}_{2}$ gas analyzer drawing up to $2 \mathrm{~mL}$ of air samples. Sampling was done with a hypodermic needle through a silicon septum pasted on the packaging. The headspace volatiles ethylene, ethanol and acetaldehyde were sampled from the package on the initial and end of storage period.

The headspace volatiles were determined by injecting $1 \mathrm{~mL}$ gas sample into a gas chromatograph equipped with alumina 60/80/100 mesh packed column. Ethylene, $\mathrm{CO}_{2}$ and $\mathrm{O}_{2}$ standards were obtained as a mixture of $1 \mathrm{ppm}$ ethylene, $1 \% \mathrm{O}_{2}$ and $5 \%$ $\mathrm{CO}_{2}$. A $98 \mathrm{ppm}$ acetaldehyde standard was made at $2^{\circ} \mathrm{C}$ by pipetting $1 \mathrm{ml}$ of pure acetaldehyde on a piece of filter paper and moved to $23^{\circ} \mathrm{C}$ and allowed to come to equilibrium.

\section{Sensorial analysis}

Overall acceptability score determined on the basis of flavor, appearance, taste, crispness and microbial limit tests parameters of samples by a panel of testers based on rating with nine point Hedonic scale given by Amerine et al., (1965) was considered. Overall rating was calculated and a score of 5.0 and above was considered as acceptable. Products that obtained less than 5.0 score were terminated.

\section{Statistical analysis}

The data was reported as an average value of replicates with standard deviation. Analysis of variance (ANOVA) was performed using IBM SPSS statistics 22 (Windows 8.1, Statistical analysis). The level of significance for all the tests was $\alpha=0.05$. Followed by Duncan's Multiple Range Test $(P \leq 0.05)$ was carried out to evaluate significant statistical difference of data. For the data expressed as proportions arcsine transformation was applied before analysis.

\section{Results and Discussion}

\section{Headspace gas concentrations}

Oxygen, carbon dioxide and ethylene content in the modified atmosphere packagings with different composition of gases containing fresh-cut lettuce leaves were analyzed (Fig. 1). Changes in package compositions during storage are a function of different gas compositions undertaken for study. In $\mathbf{M}_{1}$ treatment percent oxygen in packaged freshcut lettuce was 20.97. In $\mathrm{M}_{2}, \mathrm{M}_{3}$ and $\mathrm{M}_{4}$ oxygen maintained was $0.00,5.00$ and $3.00 \%$ respectively (Fig. 1). The maximum concentration of oxygen $(14.6 \%)$ recorded in $\mathrm{M}_{1}$ (control) in the headspace while $\mathrm{M}_{2}, \mathrm{M}_{3}$ and $\mathrm{M}_{4}$ recorded $0.567,2.827$ and 2.547 percent headspace oxygen concentration respectively (Fig. 1). During entire storage period of up to 15 days at $5^{\circ} \mathrm{C}, \mathrm{M}_{4}$ packagings treatment $(10 \%$ carbon dioxide plus $3 \%$ oxygen) showed minimum oxygen $(0.037 \%)$ in headspace (Fig. 1) The maximum consumption of oxygen was recorded in the $\mathrm{M}_{1}$ (control)indicating oxygen utilization in physiological processes (Fig. 1).

During measurement before storage, carbon dioxide concentration increased in all treatment (Fig. 1). The carbon dioxide concentration in headspace of packages had shown increasing trend irrespective of modified atmosphere packagings. During entire storage period of up to 15 days at $5^{\circ} \mathrm{C}$, $\mathrm{M}_{4}$ packagings treatment (10\% carbon dioxide plus $3 \%$ oxygen) registered minimum changes in carbon dioxide concentration (9.798 to $10.820 \%$ ) in headspace while treatment $\mathrm{M}_{1}$ recorded maximum increase of carbon dioxide (from 5.045 to $10.043 \%$ ) at all the stages of storage (Fig. 1).

Decrease in oxygen concentrations and increase in $\mathrm{CO}_{2}$ was less in $\mathrm{M}_{4}\left(10 \% \mathrm{CO}_{2}\right.$ plus $3 \% \mathrm{O}_{2}$ ). It might be due to less respiration rate 
as reported by Kim et al., (2005) and Mattos et al., (2013) on Crisphead lettuce in fresh-cut Romaine lettuce study. A rapid consumption of oxygen and evolution of $\mathrm{CO}_{2}$ was noticed in $\mathrm{M}_{1}$ (Control) (Fig. 1). This might be due to high rate of physiological activities like respiration, polyphenol oxidase activities and transpiration losses as reported by MartinBelloso et al., (2006) in fresh-cut fruits and vegetables and by Manolopoulou et al., (2010) in fresh-cut Romaine lettuce.

At the beginning of the storage, initial ethylene concentration in the headspace of fresh-cut lettuce was $0.548 \mathrm{ppm}$ and significantly influenced by various modified atmosphere packagings treatments. Significantly high ethylene concentration (0.676 ppm) was recorded in $\mathrm{M}_{1}$ (Passive MAP) at $3^{\text {rd }}$ day of storage (Fig. 1). Among all the MAP treatments, M4registered the minimum ethylene concentration $(0.844 \%)$ throughout the storage period (Fig. 1). The ethylene biosynthesis is relatively very less in fresh-cut lettuce leaves packed in different atmospheric compositions over 15 days of storage period (Fig. 1). This might be due to the occurrence of climacteric peak of ethylene production in early hours after minimal processing as reported by Kim et al., (2005) and Mattos et al., (2013) in minimally processed lettuce.

Table.1 Effect of modified atmosphere packagings on the colour appearance and flavour of the pretreated fresh-cut lettuce stored at $5 \pm 1^{0} \mathrm{C}$

\begin{tabular}{|c|c|c|c|c|c|c|c|c|c|c|}
\hline \multirow{2}{*}{ Treatment } & \multicolumn{5}{|c|}{ Color and appearance (Score) } & \multicolumn{5}{|c|}{ Flavor (Score) } \\
\hline & 3 & 6 & 9 & 12 & 15 & 3 & 6 & 9 & 12 & 15 \\
\hline Initial value & 9.00 & 9.00 & 9.00 & 9.00 & 9.00 & 9.00 & 9.00 & 9.00 & 9.00 & 9.00 \\
\hline $\mathbf{M}_{1}$ & $8.650^{\mathrm{b}}$ & $8.050^{\mathrm{c}}$ & $7.550^{\mathrm{d}}$ & $6.800^{\mathrm{c}}$ & - & $8.550^{\mathrm{b}}$ & $8.250^{\mathrm{b}}$ & $7.650^{\mathrm{c}}$ & $6.850^{\mathrm{d}}$ & - \\
\hline $\mathbf{M}_{2}$ & $8.800^{\mathrm{a}}$ & $8.650^{\mathrm{a}}$ & $8.025^{\mathrm{b}}$ & $7.550^{\mathrm{a}}$ & $7.300^{\mathrm{b}}$ & $8.625^{\mathrm{b}}$ & $8.425^{\mathrm{a}}$ & $8.125^{\mathrm{b}}$ & $7.450^{\mathrm{b}}$ & $7.200^{\mathrm{b}}$ \\
\hline $\mathbf{M}_{3}$ & $8.775^{\mathrm{ab}}$ & $8.500^{\mathrm{b}}$ & $7.850^{\mathrm{c}}$ & $7.375^{\mathrm{b}}$ & $6.85^{\mathrm{c}}$ & $8.575^{\mathrm{b}}$ & $8.275^{\mathrm{b}}$ & $8.025^{\mathrm{b}}$ & $7.350^{\mathrm{c}}$ & $6.825^{\mathrm{c}}$ \\
\hline $\mathbf{M}_{4}$ & $8.850^{\mathrm{a}}$ & $8.675^{\mathrm{a}}$ & $8.250^{\mathrm{a}}$ & $7.600^{\mathrm{a}}$ & $7.500^{\mathrm{a}}$ & $8.875^{\mathrm{a}}$ & $8.500^{\mathrm{a}}$ & $8.325^{\mathrm{a}}$ & $7.650^{\mathrm{a}}$ & $7.300^{\mathrm{a}}$ \\
\hline $\mathbf{M}_{5}$ & $8.650 \mathrm{~b}$ & $6.475^{\mathrm{d}}$ & - & - & - & $8.325^{\mathrm{c}}$ & $7.550^{\mathrm{c}}$ & - & - & - \\
\hline SE & 0.033 & 0.039 & 0.035 & 0.028 & 0.037 & 0.032 & 0.030 & 0.048 & 0.029 & 0.026 \\
\hline CD at $1 \%$ & 0.137 & 0.164 & 0.150 & 0.121 & 0.171 & 0.132 & 0.126 & 0.209 & 0.125 & 0.108 \\
\hline '-' indicates $t$ & nation c & reatmer & & & & can's N & Itiple $\mathrm{R}$ & Test & $=0.05)$ & \\
\hline $\mathrm{M}_{1}$ : Air/ Pass & MAP & & & & & $\mathrm{M}_{2}: 10$ & Nitrog & flushing & & \\
\hline $\mathrm{M}_{3}: 95 \%$ Nitr & $\mathrm{n}+5 \% \mathrm{C}$ & ygen flu & & & & $\mathrm{M}_{4}: 10$ & Carbon & ioxide + & $\%$ Oxy & flushing \\
\hline
\end{tabular}

$\mathrm{M}_{5}$ : Perforated Film Packagings (10 holes @ $1.5 \mathrm{~mm}$ per packet)

Table.2 Effect of post-harvest treatments on the taste, crispness and overall acceptability score of the pretreated fresh-cut lettuce stored at $5 \pm 1{ }^{0} \mathrm{C}$

\begin{tabular}{|c|c|c|c|c|c|c|c|c|c|c|c|c|c|c|c|}
\hline \multirow[t]{2}{*}{ Treatments } & \multicolumn{5}{|c|}{$\begin{array}{c}\text { Taste } \\
\text { Storage period in days }\end{array}$} & \multicolumn{5}{|c|}{$\begin{array}{c}\text { Crispness } \\
\text { Storage period in days }\end{array}$} & \multicolumn{5}{|c|}{$\begin{array}{l}\text { Overall acceptability } \\
\text { Storage period in days }\end{array}$} \\
\hline & 3 & 6 & 9 & 12 & 15 & 3 & 6 & 9 & 12 & 15 & 3 & 6 & 9 & 12 & 15 \\
\hline $\begin{array}{l}\text { Initial } \\
\text { Value }\end{array}$ & 9.00 & 9.00 & 9.00 & 9.00 & 9.00 & 9.00 & 9.00 & 9.00 & 9.00 & 9.00 & 9.00 & 9.00 & 9.00 & 9.00 & 9.00 \\
\hline $\mathbf{M}_{1}$ & $8.625^{\mathrm{b}}$ & $8.375^{\mathrm{c}}$ & $7.700^{\mathrm{d}}$ & $7.375^{\mathrm{c}}$ & - & 8.625 & 8.375 & 7.7 & 7.375 & - & $8.650^{\mathrm{b}}$ & $8.050^{\mathrm{c}}$ & $7.550^{\mathrm{d}}$ & $6.800^{\mathrm{c}}$ & - \\
\hline $\mathbf{M}_{2}$ & $8.675^{\mathrm{b}}$ & $8.500^{\mathrm{b}}$ & $8.350^{\mathrm{b}}$ & $7.550^{\mathrm{a}}$ & $7.350^{\mathrm{b}}$ & 8.675 & 8.5 & 8.35 & 7.675 & 7.450 & $8.800^{\mathrm{a}}$ & $8.650^{\mathrm{a}}$ & $8.025^{\mathrm{b}}$ & $7.55^{\mathrm{a}}$ & $7.300^{\mathrm{b}}$ \\
\hline $\mathbf{M}_{3}$ & $8.650^{\mathrm{b}}$ & $8.400^{\mathrm{c}}$ & $8.250^{\mathrm{c}}$ & $7.675^{\mathrm{b}}$ & $7.250^{\mathrm{c}}$ & 8.65 & 8.4 & 8.25 & 7.55 & 7.250 & $8.775^{\mathrm{ab}}$ & $8.500^{\mathrm{b}}$ & $7.850^{\mathrm{c}}$ & $7.375^{\mathrm{b}}$ & $6.850^{\mathrm{c}}$ \\
\hline $\mathbf{M}_{4}$ & $8.925^{\mathrm{a}}$ & $8.700^{\mathrm{a}}$ & $8.450^{\mathrm{a}}$ & $7.750^{\mathrm{a}}$ & $7.525^{\mathrm{a}}$ & 8.925 & 8.7 & 8.45 & 7.75 & 7.525 & $8.850^{\mathrm{a}}$ & $8.675^{\mathrm{a}}$ & $8.250^{\mathrm{a}}$ & $7.600^{\mathrm{a}}$ & $7.500^{\mathrm{a}}$ \\
\hline $\mathbf{M}_{5}$ & $8.300^{c}$ & $6.450^{\mathrm{d}}$ & - & - & - & 8.3 & 6.45 & - & - & - & $8.650^{b}$ & $6.475^{\mathrm{d}}$ & & & \\
\hline SE & 0.039 & 0.036 & 0.032 & 0.104 & 0.028 & 0.039 & 0.036 & 0.032 & 0.034 & 0.028 & 0.033 & 0.039 & 0.035 & 0.028 & 0.037 \\
\hline CD at $1 \%$ & 0.163 & 0.149 & 0.139 & 0.146 & 0.127 & 0.164 & 0.150 & 0.139 & 0.146 & 0.127 & 0.137 & 0.164 & 0.150 & 0.121 & 0.171 \\
\hline \multicolumn{6}{|c|}{ "“_' indicates termination of treatments } & \multicolumn{10}{|c|}{ *Duncan's Multiple Range Test $(P \leq 0.05)$} \\
\hline \multicolumn{6}{|c|}{$\mathrm{M}_{1}:$ Air/ Passive MAP } & \multicolumn{10}{|c|}{$\mathrm{M}_{2}: 100 \%$ Nitrogen flushing } \\
\hline \multicolumn{6}{|c|}{$\mathrm{M}_{3}: 95 \%$ Nitrogen $+5 \%$ Oxygen flushing } & & & & \multicolumn{7}{|c|}{$\mathrm{M}_{4}: 10 \%$ Carbon dioxide $+3 \%$ Oxygen flushing } \\
\hline
\end{tabular}


Fig.1 Effect of modified atmosphere packagings on headspace gas concentrations in the packages of pretreated fresh-cut lettuce stored at $5 \pm 1{ }^{0} \mathrm{C}$
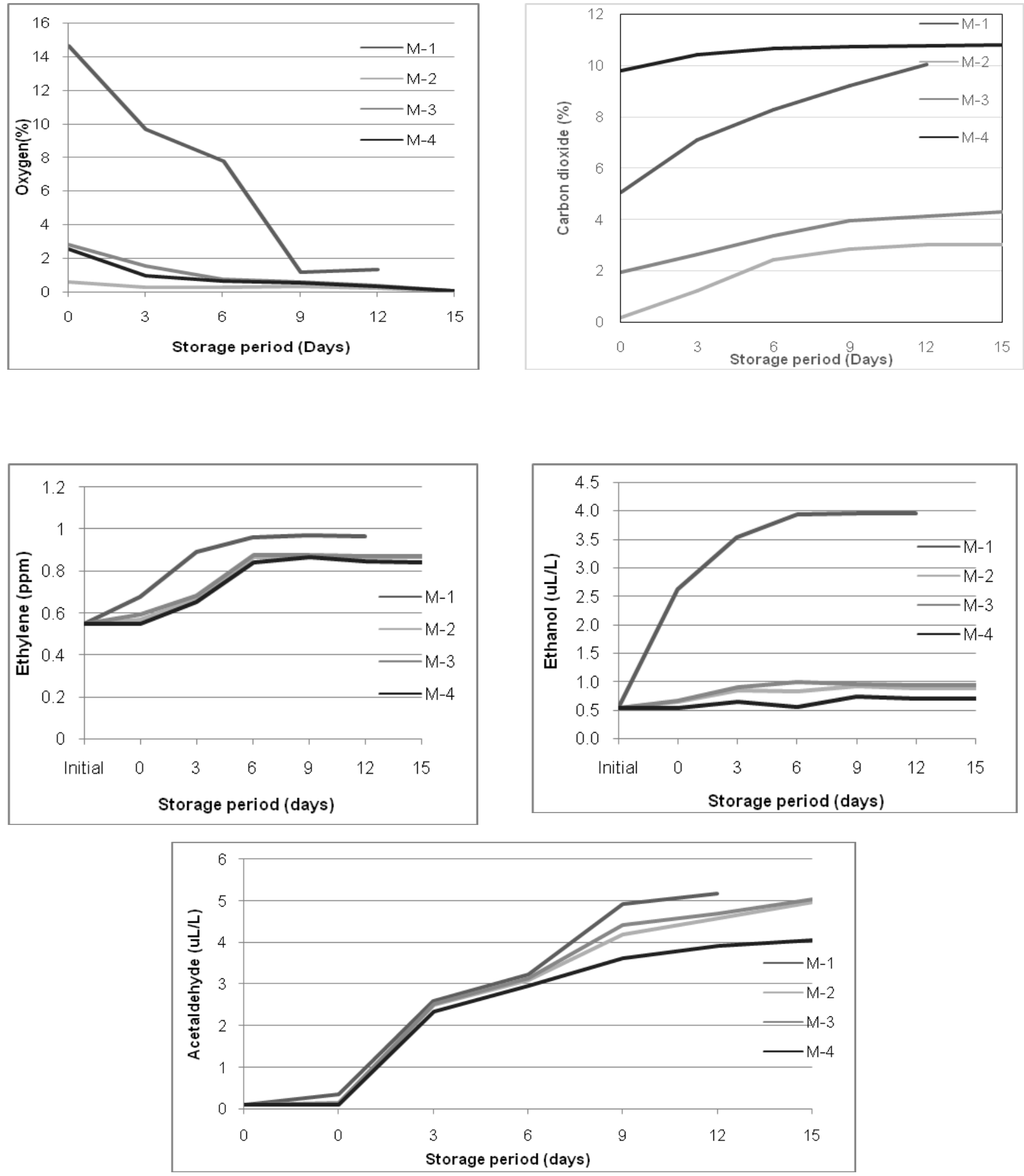

M-1 : Air/ Passive MAP

M-3: $95 \%$ Nitrogen + 5\% Oxygen flushing

M-5: Perforated Film Packagings (10 holes @ 1.5 mm per packet)
M-2: $100 \%$ Nitrogen flushing

M-4 : 10\% Carbon dioxide $+3 \%$ Oxygen flushing 
After that a slight change was observed in all packagings irrespective of packagings treatments. However, minimum increase was observed in $\mathrm{CO}_{2}$ enriched atmosphere $\left(\mathrm{M}_{4}\right)$ because of less respiration and antimicrobial effect of carbon dioxide which was supplemented with low storage temperature $\left(5^{\circ} \mathrm{C}\right)$ as reported by Sandhya (2010) in fresh produce. At $5^{0} \mathrm{C}$, as the storage period advanced, ethanol concentration in the headspace was increased gradually (Fig. 1). The maximum increase in the headspace ethanol concentration (3.954 $\mu \mathrm{LL}^{-1}$ ) was recorded by $\mathrm{M}_{1} . \mathrm{M}_{4}$ (10\% carbon dioxide plus $3 \%$ oxygen) registered the minimum ethanol concentration $\left(0.696 \mu \mathrm{LL}^{-1}\right)$ in the headspace of lettuce packages over the storage period (Fig. 1).

Initial acetaldehyde concentration in the headspace of modified atmosphere packaged fresh-cut lettuce bags was significantly influenced by treatments under study. Among all MAP treatments, $\mathrm{M}_{4}(10 \%$ carbon dioxide plus $3 \%$ oxygen) treatment registered the minimum acetaldehyde release $\left(4.050 \mu \mathrm{LL}^{-1}\right)$ in headspace of fresh cut lettuce packages up to $15^{\text {th }}$ day of storage at $5^{0} \mathrm{C}$ while maximum concentration $\left(5.17 \mu \mathrm{LL}^{-1)}\right.$ of acetaldehyde was recorded in control $\left(\mathrm{M}_{1}\right)$ up to 12 days (Fig. 1). Variation in fermentative volatile production among modified atmosphere packagings treatments was observed (Fig. 1). This might be due to the different rates of oxygen concentration and $\mathrm{CO}_{2}$ accumulation inside the package. Maximum ethanol and acetaldehyde was observed in $\mathrm{M}_{1}$ (control). This might be to the higher respiratory activity on initial stages and anaerobic conditions in late stages which led to fermentation process. The Similar results were reported by Kim et al., (2005) on Romaine lettuce and by Escalaona et al., (2007) in freshcut lettuce.

\section{Sensorial analysis}

With the advancement of storage period, overall acceptability of fresh-cut lettuce decreased irrespective MAP treatment (Table 2). Score for overall acceptability of fresh-cut lettuce was significantly influenced by MAP conditions. At the end of $6^{\text {th }}$ day of storage, $M_{5}$ (perforated packaging) treatment registered lowest score (6.475) for the overall acceptability. The MAP conditions $\mathrm{M}_{4}(10 \%$ carbon dioxide plus $3 \%$ oxygen) recorded maximum acceptability score (7.500) throughout the storage period of 15 days (Table 2). The pre-treated lettuce fresh-cut leaves packaged with $10 \%$ carbon dioxide and $3 \%$ oxygen maintained or enhanced colour and appearance, taste, flavor, retained freshness, crispness and recorded maximum acceptability score (7.500) throughout the storage period of 15 days (Table 1 and 2).This maintained fresh like quality upto 15 days at $5^{\circ} \mathrm{C}$ followed by 100 $\%$ nitrogen flushing packagings (Table 1 and Table 2).The carbon dioxide enriched atmosphere, $\mathrm{M}_{4}\left(\begin{array}{lll}10 \% & \mathrm{CO}_{2}+3 \% \mathrm{O}_{2}\end{array}\right)$ reported higher score at all stages (days) for all visual quality markers viz., appearance, taste, flavor, crispness and overall acceptability (Table 1 and 2). The modified atmosphere packagings recorded maximum score at the end of storage period as compared to control $\left(\mathrm{M}_{1}\right)$. This maximum overall acceptability in $\mathbf{M}_{4}$ might be due to the effectiveness of carbon dioxide enrichment which led to reduced enzymatic browning, minimum decay, minimum moisture and physiological loss in weight. The similar results were reported by Escalano et al., (2007), Hamza et al., (2007) and Barriga et al., (2006) in minimally processed lettuce at cold storage conditions.

MAP with $10 \%$ carbon dioxide plus $3 \%$ oxygen flushing and MAP with $100 \%$ nitrogen flushing extended shelf life of pretreated fresh cut lettuce up to 12-15 days when stored at $5 \pm 1^{0} \mathrm{C}$. Pretreated fresh-cut lettuce packaged in perforated bags $\left(\mathrm{M}_{5}\right)$ recorded shelf life up to 6 days only. The control (air/passive MAP) treatment recorded maximum decrease in physicochemical and sensorial parameters with rapid increase in microbial count at $5 \pm 1{ }^{\circ} \mathrm{C}$. Decrease in percent moisture, ascorbic acid, polyphenol, headspace oxygen and sensory parameters while increase in physiological loss in weight, headspace carbon dioxide, ethylene, ethanol, acetaldehyde concentrations and 
microbial count was recorded in all MAP conditions. The MAP treatment, $\mathrm{M}_{4}\left(10 \% \mathrm{CO}_{2}\right.$ plus $3 \% \mathrm{O}_{2}$ ) recorded minimum changes in physico-chemical parameter, headspace gas concentrations with minimum accumulation of volatiles, and minimum microbial count under refrigerated storage.

\section{References}

Allende, A., F.A. Tomas-Barberan and M.I. Gil, 2006. Minimal processing for healthy traditional foods. Trends in Food Sci. and Technol., 17:513-519.

Amerine, M.A., R.M. Pangborn and E.B. Roessler, 1965. Laboratory studies: Quantity-quality evaluation in Principles of Sensory Evaluation of Foods. Academic Press, New York. pp. 349-397.

Barriga M.I., G. Trachy, C. Willemot and R.E. Simard, 2006. Microbial changes in shredded iceberg lettuce stored under controlled atmospheres J. of Food Sci., 56(6):1586-1588.

Beltran, D., M.V. Salma, A. Marin and M.I. Gil, 2005. Ozonated water extends the shelf life of fresh-cut lettuce. J. Agric. Food Chem., 53(14): 5654-5663.

Church, N., 1994. Developments in ModifiedAtmosphere Packaging and Related Technologies, Trends in Food Science \& Tech., 5:345-352.

Dash, S.K., A. Kar and K. Gorrepati, 2013. Modified atmosphere packaging of minimally processed fruits and vegetables. Trends InPost Harvest Technol.,1(1):01-19.

Escalona, V.H., S. Geysen, B.E. Verlinden and B.M. Nicola, 2007. Microbial quality and browning of fresh cut butter lettuce under super atmospheric oxygen condition. $J$.
Hort. Sci., 72(3).130-137.

Hamza, F., F. Castaigne, C. Willemot, G. Doyon and J. Makhlouf, 2007. Storage of minimally processed romaine lettuce under controlled atmosphere. J. Food Quality., 19(3): 177-188.

Kim, G.J., Y. Luo, R.A. Saftner and K.C. Gross, 2005. Delayed modified atmosphere packaging of fresh-cut romaine lettuce: Effect on quality maintenance and shelf life. J. Amer. Soc. Hort. Sci., 130(1):116123.

Manolopoulou, H., G.R. Lambrinos, E. Chatzis, G. Xanthopoulos and E. Aravantinos, 2010. Effect of temperature and modified atmosphere packaging on storage quality of fresh-cut romaine lettuce. J. Food Quality., 33(1): 317-336.

Martin Belloso and R.C. Solivia-Fortuny, 2006. Sensory quality and internal atmosphere of fresh-cut golden delicious apples. Int. $J$. Food Sci. Technol., 40(6): 369.

Mattos, L.M., C.L. Moretti and E.Y.Y. Silva, 2013. Effects of modified atmosphere packaging on quality attributes and physiological responses of fresh-cut crisphead lettuce. J. Food., 11(4):392-397.

Rico, D., A.B. Martin-Diana, J.M. Frias, G.T.M. Henhen and C. Barry-Ryan, 2006. Effect of ozone and calcium lactate treatments on browning and texture properties of fresh-cut lettuce. J. Food Sci. Agric., 86: 2179-2188.

Sandhya, 2010. Modified atmosphere packaging of fresh produce: Current status and future needs. LWT - Food Science and Technology, 43:381-392.

Steinmetz, K.A. and J.D. Potter, 1996. Vegetables, fruit and cancer prevention: A review. J Amer. Dietetic Association, 96: $1027-1036$.

\section{How to cite this article:}

Manpreet Kaur, S.S. Dhumal, V.K. Garande, D.R. Patgaonkar, A.G. Bhoite and Patil, S.S. 2017. Effect of Modified Atmosphere Packaging on Headspace Gas Concentrations Including Volatiles and Sensorial Attributes of Fresh-Cut Lettuce. Int.J.Curr.Microbiol.App.Sci. 6(11): 2142-2148. doi: https://doi.org/10.20546/ijcmas.2017.611.252 